\title{
A Systematic Review on the Intersection of Homelessness and Healthcare in Canada
}

\author{
Vivian Darkwah ${ }^{1}$, Hiroko Yamane ${ }^{2}$, Solina Richter ${ }^{3 *}$, Vera Caine ${ }^{4}$, Geoffrey Maina ${ }^{1}$, Thane Chambers ${ }^{5}$ and Leanne Johnson ${ }^{1}$ \\ ${ }^{1} P h D$ Student, University of Alberta, Faculty of Nursing, Edmonton, Alberta, Canada \\ ${ }^{2}$ Master of Nursing, University of Alberta, Faculty of Nursing, Edmonton, Alberta, Canada \\ ${ }^{3}$ Associate Professor, University of Alberta, Faculty of Nursing, Edmonton, Alberta, Canada \\ ${ }^{4}$ Assistant Professor, University of Alberta, Faculty of Nursing, Edmonton, Alberta, Canada \\ ${ }^{5}$ Research Librarian, University of Alberta, Faculty of Nursing, Edmonton, Alberta, Canada
}

\begin{abstract}
Background: Nurses must understand the needs and barriers of people who are homeless when they are in a health care environment in order to render effective care.

Objective: The objective of this review is to synthesize research findings on studies that examine the needs and barriers of people who are homeless in Canada when they intersect with health care providers.

Methods: A scope of manuscripts, published in English from 1980 to 2011 that assess the needs and barriers of people experiencing homelessness in Canada when in the health sector without limitation on study design from different electronic databases and manual searches, was conducted.
\end{abstract}

Results: Six articles ( $\mathrm{N}=4$ qualitative, $\mathrm{N}=2$ quantitative) met the inclusion and exclusion criteria. Eight themes emerged from a narrative synthesis of the findings.

Conclusion: Individuals who are homeless have multiple needs when in the health care sector. Thus, collaboration among different disciplines is essential in order to provide them with holistic care.

Keywords: Homelessness; Needs; Intersection; Health care providers; Barriers

\section{Introduction}

Homelessness increases an individual's risk to serious health conditions and multiple barriers in everyday life [1]. When the physical health conditions of people who are homeless is compared to the general population, the rates of nearly all chronic illnesses and physical ailments among the population experiencing homelessness are higher, particularly higher prevalence of hepatitis, diabetes, heart and lung disease, cancer, psychiatric conditions and infectious diseases are found [2-3]. Unintentional injuries such as falls or being struck by a vehicle are common problems among this population, especially men experiencing homelessness [3]. People who are homeless have more visits to emergency departments and more hospitalizations than the general population [4-7]. When they eventually seek help, they are usually sicker, need more intensive treatment, and their mortality rates are greater than the non-homeless population [8,9]. In addition, many complex and intersecting barriers between people experiencing homelessness and health care providers exist and prevent them from seeking help. There is limited study on the priority needs of the homeless when they meet health care professional. Hence, the purpose of this systematic review is to find out what is known about the needs and barriers of people experiencing homelessness when they meet with health care providers.

\section{Research Question}

What are the needs and barriers of people experiencing homelessness in Canada when they meet health care providers?

\section{Methods}

\section{Inclusion and exclusion criteria}

The inclusion criteria that guided the review were studies conducted in Canada and focused on the needs and barriers of people who are homeless when they intersect with health care providers. The review team included research articles that ranged from quantitative designs such as quasi experimental designs, longitudinal, case-control, descriptive and correlation studies, as well as qualitative studies and grey literature. The study population covers people experiencing homelessness which involves men, women, children, youth, adult and elderly who resided in shelters, street, parks, bridges, or were couch surfing in Canada. Our definition of homeless has focused on individuals who lack permanent or stable housing. The study outcomes included the needs of people who are homeless when they are in the health care setting such as need to see their physicians, obtain medication and supplies and the barriers they encounter such as stigmatization, lack of access to health care cards, marginalization, and lack of permanent home address. Studies were excluded if they were on the opinions of health service providers.

\section{Search strategy}

An initial scoping search was conducted with the assistance of a Librarian to ensure the search terms used retrieved all possible studies conducted and published on the topic. After the initial scoping search with the librarian, two research assistants conducted detailed search from January to February 2011 covering the following electronic databases: Medline, CINAHL, EMBASE, Psycinfo, Cochrane Library, Scopus, PROQUEST, Eric, Sociological Abstract and Sociological Index. Searches were taken from articles published from 1980 to 2011, the period when publications on homelessness became visible in Canada. Both controlled vocabulary and keywords were used in the search strategy. The search terms used were homeless, roofless, street youth, vagrant, tent city, inner city, shelter and Canada. The search terms and

*Corresponding author: Solina Richter, Associate Professor, Faculty of Nursing University of Alberta, Edmonton Alberta, Canada, Tel: 780492 7953; Fax: 780492 2551; E-mail: solina.richter@ualberta.ca

Received May 25, 2012; Accepted June 25, 2012; Published June 27, 2012

Citation: Darkwah V, Yamane H, Richter S, Caine V, Maina G, et al. (2012) A Systematic Review on the Intersection of Homelessness and Healthcare in Canada. J Nurs Care 1:115. doi:10.4172/2167-1168.1000115

Copyright: @ 2012 Darkwah V, et al. This is an open-access article distributed under the terms of the Creative Commons Attribution License, which permits unrestricted use, distribution, and reproduction in any medium, provided the original author and source are credited. 
strategy were adapted for each of the databases. Broad search terms were used in order not to exclude any essential study. Furthermore, reference lists of all retrieved studies were searched for additional manuscripts. A manual search of important journals such as Canadian Journal of Public Health, Canadian Medical Association Journal, Canadian Journal of Nursing Research, and Journal of Advanced Nursing was also conducted. Unpublished literature, referred to as grey literature, was searched from online sites of relevant institutions and associations (hospitals, non-profit and government organizations). Additionally, Google searches with the above key words were done. Both published and unpublished works by key authors in the field of homelessness were searched and appropriate articles retrieved. The search continued until no additional articles were retrieved. Two reviewers independently read through the abstracts of relevant articles to select the appropriate studies for full review. The two reviewers who screened the abstracts met to compare and agree on articles that met the inclusion criteria. Any unresolved decision on an article was sent to a third reviewer for final decision. Complete manuscripts of studies that met the inclusion and exclusion criteria were retrieved and read by all the six team members for inclusion in the study (Figure 1).

\section{Quality assessment}

Out of the six articles that met the inclusion criteria, four were qualitative studies, and two quantitative designs. Each manuscript's methodological quality was assessed by three independent reviewers using the critical appraisal skills programme (CASP) for qualitative research [10]. The JBI-Meta analysis of statistics Assessment and review instrument for descriptive/correlational studies was used for the quantitative design [11]. The three reviewers met to discuss their findings and resolve areas they did not agree on. Primary areas of disagreement were retrieved articles' objectives or target population and relevance of the research findings to our topic of interest.

\section{Results}

A total of thirty (30) full articles relevant to the research question were identified. Eighteen articles were excluded either because the setting for the manuscripts was not in Canada, they were not research manuscripts, and their goals were not on the needs of people who are homeless when they meet with health care professionals. Five articles were retrieved through a grey literature search. There was no article obtained from the list of reference that was searched. Each team member read two full articles. Six out of the twelve full articles read were accepted to be included in the review for quality assessment and data extraction.

\section{Data extraction and synthesis}

Following the quality check, two researchers independently read each article to obtain data in relation to the study's objective using a

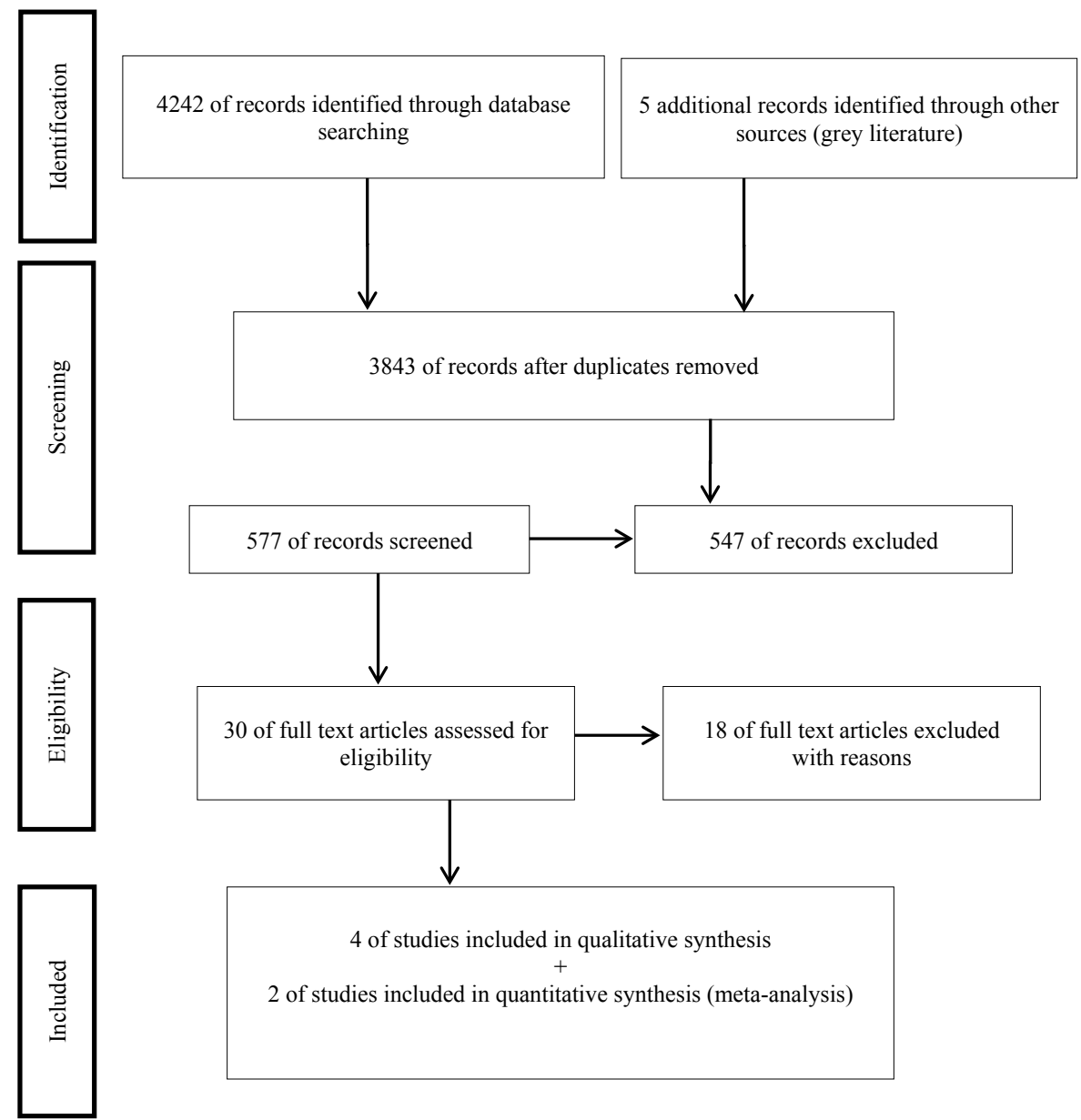

Figure 1: Flow diagram showing literature search and selection of required manuscripts. 
framework [12]. The review findings included few articles (six studies) that met the inclusion criteria and these manuscripts were both quantitative $(\mathrm{N}=2)$ and qualitative studies $(\mathrm{N}=4)$. Hence, synthesis of data could not be pooled using a meta- analysis. Narrative synthesis was used to combine the findings from the studies by examining significant themes and differences among studies $[13,14]$. The results from the review are reported under the identified themes. The table below illustrates the data extraction of manuscripts included in the review (Table 1).

\section{Quality}

Two authors clearly defined homelessness $[15,16]$. The other four authors concur with the two author's definition of homelessness which is used in this review. Two studies used quantitative designs [16,17]. Only Hwang et al. [16] used a standardized tool and a cross section design to collect data however the authors did not discussed ways to prevent attrition. Hwang and Bugeja [17] used a survey and indicated the attrition rate but did not give the probable reasons for the dropout.
The four other studies used qualitative designs $[8,15,18,19]$ and followed the principles of the design selected for example they fully describe the research context, sampling, ethics, and data analysis.

\section{Findings}

The themes that emerged from the six manuscripts on the experiences of people who are homeless when they meet health care professionals are reported below.

\section{Chronic physical and mental health conditions}

All the authors reported that people who are homeless do have one or more chronic physical conditions including seizure disorders, diabetes, long standing respiratory tract disease, musculoskeletal illness, eye/dental problems and communicable disease like tuberculosis. Furthermore, this population do experience mental health problems such as depression, drug addiction, stress and suicide [8]. Another investigator note that the presence of these chronic illnesses and mental health issues increase the likelihood that people who are homeless will

\begin{tabular}{|c|c|c|c|c|c|}
\hline $\begin{array}{l}\text { Authors/ Years of pub- } \\
\text { lication }\end{array}$ & $\begin{array}{l}\text { Method of data collec- } \\
\text { tion/Study type }\end{array}$ & Setting/Partici- pants & Objectives & Findings & Conclusion \\
\hline Hwang \& Bugeja (2000) & $\begin{array}{l}\text { Survey Face to face } \\
\text { interview. }\end{array}$ & $\begin{array}{l}18 \text { shelters for single adults in } \\
\text { Toronto, Canada } \\
50 \text { people with type } 2 \text { diabetes } \\
\text { living at shelters }\end{array}$ & $\begin{array}{l}\text { Assessed barriers } \\
\text { people experiencing } \\
\text { homelessness encoun- } \\
\text { ter in obtaining the } \\
\text { necessities of life }\end{array}$ & $\begin{array}{l}72 \% \text { experienced difficul- } \\
\text { ties in managing diabetes } \\
\text { and } 44 \% \text { had inadequate } \\
\text { glycemic control. } \\
\text { (1) } 18 \% \text { reported inability to } \\
\text { schedule medications with } \\
\text { meals. }\end{array}$ & $\begin{array}{l}\text { Shelters should provide efficient } \\
\text { access to health care (seeing } \\
\text { a physician) by scheduling ap- } \\
\text { pointment through shelter. }\end{array}$ \\
\hline $\begin{array}{l}\text { McCormack \& Mclntosh } \\
(2001)\end{array}$ & $\begin{array}{l}\text { Guided interview } \\
\text { Grounded theory }\end{array}$ & $\begin{array}{l}3 \text { shelters in New Brunswick } \\
\text { cities, Canada } \\
11 \text { people aged between } 17 \text { to } \\
56 \text { years. }\end{array}$ & $\begin{array}{l}\text { Understand how } \\
\text { individuals who are } \\
\text { homeless in three } \\
\text { New Brunswick cities } \\
\text { describe their health } \\
\text { experience and strate- } \\
\text { gies they use to attain, } \\
\text { maintain or regain } \\
\text { health }\end{array}$ & $\begin{array}{l}\text { People experiencing } \\
\text { homeless- } \\
\text { ness address their health- } \\
\text { care needs initially through } \\
\text { lifestyle behaviours before } \\
\text { accessing formal services. }\end{array}$ & $\begin{array}{l}\text { People experiencing homeless- } \\
\text { ness chief concern is meeting } \\
\text { survival needs like shelter and } \\
\text { food. }\end{array}$ \\
\hline Daiski (2006) & $\begin{array}{l}\text { Semi-structured } \\
\text { interview } \\
\text { Descriptive explor- } \\
\text { atory design }\end{array}$ & $\begin{array}{l}\text { Public spaces such as city } \\
\text { parks, on streets, and women's } \\
\text { drop-in centre in one city } \\
\text { Canada } \\
24 \text { people experiencing home- } \\
\text { lessness ( } 9 \text { women/15 men } \\
\text { aged from } 19 \text { to } 81 \text { years). }\end{array}$ & $\begin{array}{l}\text { Explore the views of } \\
\text { people who are home- } \\
\text { less on their health and } \\
\text { health care needs }\end{array}$ & $\begin{array}{l}\text { (1) People who are home- } \\
\text { less feel they do not have } \\
\text { dignity and self-worth. } \\
\text { (2)People experiencing } \\
\text { homelessness are ignored } \\
\text { by people and health care } \\
\text { professionals. }\end{array}$ & $\begin{array}{l}\text { Shelters should be used as a } \\
\text { short term solution to homeless- } \\
\text { ness and not a long term one. } \\
\text { Health care workers should } \\
\text { negotiate for people who are } \\
\text { homeless to obtain housing, } \\
\text { healthcare, training and employ- } \\
\text { ment. }\end{array}$ \\
\hline $\begin{array}{l}\text { Haldenby, Berman \& } \\
\text { Forchuk } \\
(2007)\end{array}$ & $\begin{array}{l}\text { Semi-structured } \\
\text { interview } \\
\text { Critical narrative } \\
\text { analysis }\end{array}$ & $\begin{array}{l}\text { A community centre in a down- } \\
\text { town area of a south-western } \\
\text { city in Ontario } \\
13 \text { youth experiencing home- } \\
\text { lessness } \\
\text { ( } 6 \text { young women and } 7 \text { young } \\
\text { men aged from } 14 \text { to } 19 \text { years) }\end{array}$ & $\begin{array}{l}\text { Explore the experi- } \\
\text { ence of homelessness } \\
\text { among adolescents }\end{array}$ & $\begin{array}{l}\text { (1) They will use conven- } \\
\text { tional forms of health care } \\
\text { (emergency rooms) when } \\
\text { ill. } \\
\text { (2) They experience insen- } \\
\text { sitive care from health care } \\
\text { providers. }\end{array}$ & $\begin{array}{l}\text { The authors recommend } \\
\text { provision of affordable housing, } \\
\text { public policy and gender con- } \\
\text { sideration in offering assistance } \\
\text { since females experience more } \\
\text { distress than males. }\end{array}$ \\
\hline $\begin{array}{l}\text { Pauly } \\
(2008)\end{array}$ & $\begin{array}{l}\text { Participants observa- } \\
\text { tion } \\
\text { formal or informal } \\
\text { interviews } \\
\text { Ethnography }\end{array}$ & $\begin{array}{l}\text { Two primary health centers in } \\
\text { large Canadian cities } \\
26 \text { participants } \\
\text { (13 Registered Nurses, } 4 \\
\text { people who are homeless } \\
\text { accessing health care and } 9 \\
\text { healthcare team members) }\end{array}$ & $\begin{array}{l}\text { Explore factors that } \\
\text { could lead to harm } \\
\text { reduction in acute care }\end{array}$ & $\begin{array}{l}\text { (1) People experiencing } \\
\text { homelessness are blamed } \\
\text { for their poor health and felt } \\
\text { abandoned by healthcare } \\
\text { workers because they were } \\
\text { unfixable. } \\
\text { (2) People experiencing } \\
\text { homelessness want to be } \\
\text { treated as a 'real person' } \\
\text { when they accessed } \\
\text { healthcare. }\end{array}$ & $\begin{array}{l}\text { The authors suggest harm } \\
\text { reduction as the central focus } \\
\text { in delivering care to people who } \\
\text { are homeless. } \\
\text { Nursing curriculum must be } \\
\text { designed to include social } \\
\text { conditions that shape the lives } \\
\text { of people living on the street to } \\
\text { facilitate students' knowledge } \\
\text { on homelessness. }\end{array}$ \\
\hline Hwang et al. (2010) & Cross sectional survey & $\begin{array}{l}58 \text { shelters and } 18 \text { meal pro- } \\
\text { grams in Toronto, Canada } 1169 \\
\text { people who are homeless ( } 50 \% \\
\text { single men, } 25 \% \text { single women, } \\
\text { and } 25 \% \text { adults with dependent } \\
\text { children). }\end{array}$ & $\begin{array}{l}\text { Determine the } \\
\text { prevalence of unmet } \\
\text { needs for health care } \\
\text { among people who are } \\
\text { homeless }\end{array}$ & $\begin{array}{l}\text { (1) Disparity of access } \\
\text { to care greatest among } \\
\text { women who are homeless } \\
\text { with dependent children. } \\
\text { (2) Homeless had fears of } \\
\text { being negatively judged by } \\
\text { health care providers }\end{array}$ & $\begin{array}{l}\text { Poor physical or mental health, } \\
\text { young age, victims of physical } \\
\text { assaults and lack of health } \\
\text { insurance were associated with } \\
\text { unmet needs for health care. }\end{array}$ \\
\hline
\end{tabular}

Table1: Summary of the extracted Data. 
not have their needs met when they meet health care professionals [16] The feeling of being healthy is an essential factor to people who are homeless in order to promote their self-reliance and active participation in society [18].

\section{Inability to obtain health care services}

People experiencing homelessness in the studies reported in this review indicated that they have difficulty obtaining services such as consultation with physicians and specialist, and difficulty obtaining harm reduction materials such as needles, syringes, and prescribed medications $[16,17]$. Some participants indicated that there have been instances when their physicians requested that they see a specialist but their physicians were unsuccessful in obtaining an appointment [16]. Some participants indicated that there was no treatment available to people living on the street when they want to stop drug or addiction behaviours [8]. In addition, lack of information and knowledge about available services significantly challenge access to health care and other social services [15].

\section{Fragmentation of supports}

Participants in all the studies described the fragmented nature of support systems for people who are homeless. In McCormack and MacIntosh's study, one participant mentioned that he had to call multiple sectors to obtain needed supports such as cloth, food, shelter, and social welfare. Research shows that housing, employment, food, water, and income are the primary concerns among the homeless population rather than their health status $[15,18]$.

\section{Discrimination and stigmatization}

People experiencing homelessness have expressed that they are often negatively judged by health professionals. In addition, they are being ignored and excluded from communication about them when they are in health care setting $[8,18]$. One of Daiski's participants talks about her need for human touch and the need to talk to somebody but people pretend they do not notice her. Being ignored generates a feeling of being a failure, leading to social isolation and depression. Other participants reported that health care providers are not sensitive to their needs, do not trust them, disrespect their age and use language that creates social distance and isolation [18]. Some participants reported feeling uncomfortable when they consulted their doctors [17].

\section{Lack of health insurance}

A major barrier to their care is the lack of health insurance because their health care card is either stolen or they are no longer covered by their parent's health insurance [16] reported that $18 \%$ of the participants in their study did not have a health insurance while $31 \%$ had their card stolen. In another study, $52 \%$ of the participants did not have a health insurance card [17].

\section{Increased needs among women experiencing homelessness}

Women experiencing homelessness were more vulnerable to physical and sexual assaults which were found to be significantly associated with increased levels of unmet health care needs $[15,16]$. Women who are homeless tend to have more special health care needs related to pregnancy, feminine hygiene, STDs, or birth control which they often find supports are not available.

\section{Unfixable and abandoned}

People who are homeless often seek care at the emergency department (ED). Nurses in emergency room have a goal of fixing their patients and discharging them promptly [19]. Hence, people living on the street expressed that they are considered unfixable when the nurses and other health professionals are unable to treat them [19]. Health professionals give up on them and consider them as failures.

\section{Moral worth}

People experiencing homeless are treated inhumanely during verbal and non-verbal interactions with some health professionals when they seek health care [19]. People who are homeless frequently reported they felt like foreigners, strangers and worthless in the health sector.

\section{Discussion}

Health is a secondary need to people experiencing homeless since they are more concern about finding a roof on their head and food to eat before considering health. People without permanent place of abode have complex needs and concerns ranging from housing, employment, income, education, and health. Furthermore, they suffer from chronic physical and emotional problems such as fatigue, frustration, and depression.

An outcome from the review shows that when people who are homeless encounter health care providers, they do not only expect their health concerns to be addressed but also wish their emotional and financial needs are met. Thus, instead of focusing on health-related issues of the homeless, health care providers need to pay attention to their whole life experiences of being homeless. The question on needs which is crucial to answer on research about people experiencing homeless is: "What are the priority needs of people experiencing homeless when they meet health care professional?" Considering the number of people experiencing homelessness in Canada, it is imperative that more research is conducted to identify their priority needs.

\section{Limitations}

Some limitations were involved in answering the review question. We did not locate exact studies on the needs of people who are homeless when they meet with health care providers. Furthermore, only manuscripts reported in English language were included which predispose this review to language and publication biases. Since Canada is bi-lingual (English and French), the generalizability of this review findings is limited to English language speaking provinces.

\section{Recommendations}

There should be research on the priority needs of the marginalized such as the homeless when in the health sector in order to reach out to them, meet their needs and reduce complications associated with homelessness. Health care providers must render comprehensive care to people who are homeless.

\section{Conclusion}

Research on people experiencing homelessness has revealed that health is a secondary need to people experiencing homelessness. The priority needs of this population when accessing health services include food, shelter, clothing, respect and employment. Nurses' knowledge on the need of people who are homeless when in the health care will sensitize them to provide cares that meet the unique needs of this marginalized population. Furthermore, nurses will be able to advocate for policies that address the needs of the homeless such as free health care services, acceptance of the homeless when in the health sector and negotiate for their priority needs such as housing upon their discharge from the hospital.

\section{References}

1. Cowan L, Hwang S, Khandor E, Mason K (2007) The street health report Wellesley Institute, Toronto.

2. Crowe C (2007) The Kingston I knew.

3. Frankish CJ, Hwang SW, Quantz D (2005) Homelessness and health in Canada: Research `Lessons And Priorities. Canadian Journal of Public Health 96: 23-29. 
4. Michelen W, Martinez J, Lee A, Wheeler DP (2006) Reducing frequent flyer emergency department visits. J Health Care Poor Underserved 17: 59-69.

5. Roos LL, Walld R, Uhanova J, Bond R (2005) Physician visits, hospitalizations, and socioeconomic status: ambulatory care sensitive conditions in a Canadian setting. Health Serv Res 40: 1167-1185.

6. Shah BR, Gunraj N, Hux JE (2003) Markers of access to and quality of primary care for Aboriginal people in Ontario, Canada. Am J Public Health 93: 798-802.

7. Sin DD, Svenson LW, Cowie RL, Man SF (2003) Can universal access to health care eliminate health inequities between children of poor and non-poor families?: a case study of childhood asthma in Alberta. Chest 124: 51-56.

8. Daiski I (2007) Perspectives of homeless people on their health and health needs priorities. J Adv Nurs 58: 273-281.

9. Wen CK, Hudak PL, Hwang SW (2007) Homeless people's perceptions of welcomeness and unwelcomeness in healthcare encounters. J Gen Intern Med 22: 1011-1017.

10. Public Health Resource Unit. (2006) Critical Appraisal Skills Programme (CASP), England: Public health resource unit.

11. Jayasekara R, Schultz T, McCutcheon HA (2006) A Comprehensive systematic review of evidence on the effectiveness and appropriateness of undergraduate nursing curricula. Int J Evid Based Healthc 4: 191-207.
2. Shepherd J, Harden A, Rees R, Brunton G, Garcia J, et al. (2006) Young people and healthy eating: a systematic review of research on barriers and facilitators. Health Educ Res 21: 239-257.

13. Boaz A, Ashby D, Young K (2002) Systematic reviews: What have they got to offer evidence-based policy and practice? (Working paper 2). UK: ESRC UK Centre for Evidence Based Policy and Practice.

14. Centre for reviews and dissemination (CRD) (2009) Systematic reviews: CRD's guidance for undertaking reviews health care. United Kingdom: the university of York.

15. Haldenby AM, Berman H, Forchuk C (2007) Homelessness and health in adolescents. Qual Health Res 17: 1232-1244.

16. Hwang SW, Ueng JM, Chiu S, Kiss A, Tolomiczenko G, et al. (2010) Universal health insurance and health care access for homeless persons. Am J Public Health 100: 1454-1461.

17. Hwang SW, Bugeja AL (2000) Barriers to appropriate diabetes management among homeless people in Toronto. CMAJ 163: 161-165.

18. McCormack D, Macintosh J (2001) Research with homeless people uncovers a model of health. West J Nurs Res 23: 679-697.

19. Pauly BB (2008) Shifting moral values to enhance access to health care: harm reduction as a context for ethical nursing practice. Int J Drug Policy 19: 195204 